\title{
The Golgi Elements of Mouse Hepatic Cells Examined Refractometrically by Phase Contrast Illumination
}

\author{
Stanisław Grzycki \\ Department of Histology and Embryology of Medical Academy, \\ Lublin, Poland
}

Received November 17, 1960

Morphophysiological investigations of the Golgi substance (Golgi apparatus) of hepatic cells of various animals were carried out by Pascual (1924), Nassonov (1926), Bowen (1926), Cramer and Ludford (1926), Ludford (1928), Granel (1929), Dornesco (1929-1931), Subramaniam (1938), Gatenby and Moussa (1951), Gatenby (1955) and others. These workers using mainly silver salts methods are unanimous in the opinion that the structure of the Golgi elements, located usually at a short distance from the nucleus, are either intertwined with a typical Golgi net or may have the appearance of fragments morphologically different, dispersed round the nucleus. Shape, size and location of those elements, as Chodnik (1948) noticed, are very closely correlated with the phases of cell activity and secretory phenomena.

Demonstration of the Golgi apparatus in the hepatic cells with silver salts impregnation methods is not always successful. The methods of Da Fano, Cajal, Mann-Kopsch may result in departures. Chodnik obtained, however, successful results using the method of Mann-Kopsch and even better results after Ludford's modification. Taking into consideration my recent results of obtaining the picture of the Golgi elements in the cells fixed but unstained, after using refractometric technique by phase contrast illumination, I decided to carry out refractometric investigations of those structures in the hepatic cells of the mouse.

\section{Materials and methods}

The samples of the liver of a white mouse (Mus musculus L. albino) fixed in Helly's and Schaffer's fluids were next dehydrated in alcohol and xylene, and embedded in paraffin of $45-56^{\circ} \mathrm{C}$ melting point. Thin sections $(2-3 \mu)$ deparaffinized in xylene were examined unstained under a phase contrast Lumipan C. Zeiss (Jena) microscope using immersion objective Ph HI 90/1.25. Following strictly directions given by Hancox and Kruszyński (1956), Kruszyński (1957) and Grzycki (1958-1961) deparaffinized slices were mounted on slides in media of known RI i.e. $p$-xylene $(\mathrm{RI}=1.4968)$, $o$-xylene (RI= $1.5037)$, acetophenone $(R I=1.5338)$, di-methylaniline $(R I=1.5589)$, aniline 
$(R I=1.5828)$ and quinoline $(R I=1.6161)$. The $R I$ values of the media used for examination were determined with Zeiss Abbe Refractometer " $G$ " with the help of electric light (the bulb $120 \mathrm{~W}, 220 \mathrm{~V}$.) in room temperature $+20^{\circ} \mathrm{C}$. All phase contrast photomicrographs (Figs. 1-6) were taken with "Practina FX" camera.

\section{Observations and results}

A detailed analysis of pictures obtained in my previous investigations, by phase contrast microscope, made me suppose that the refractometric
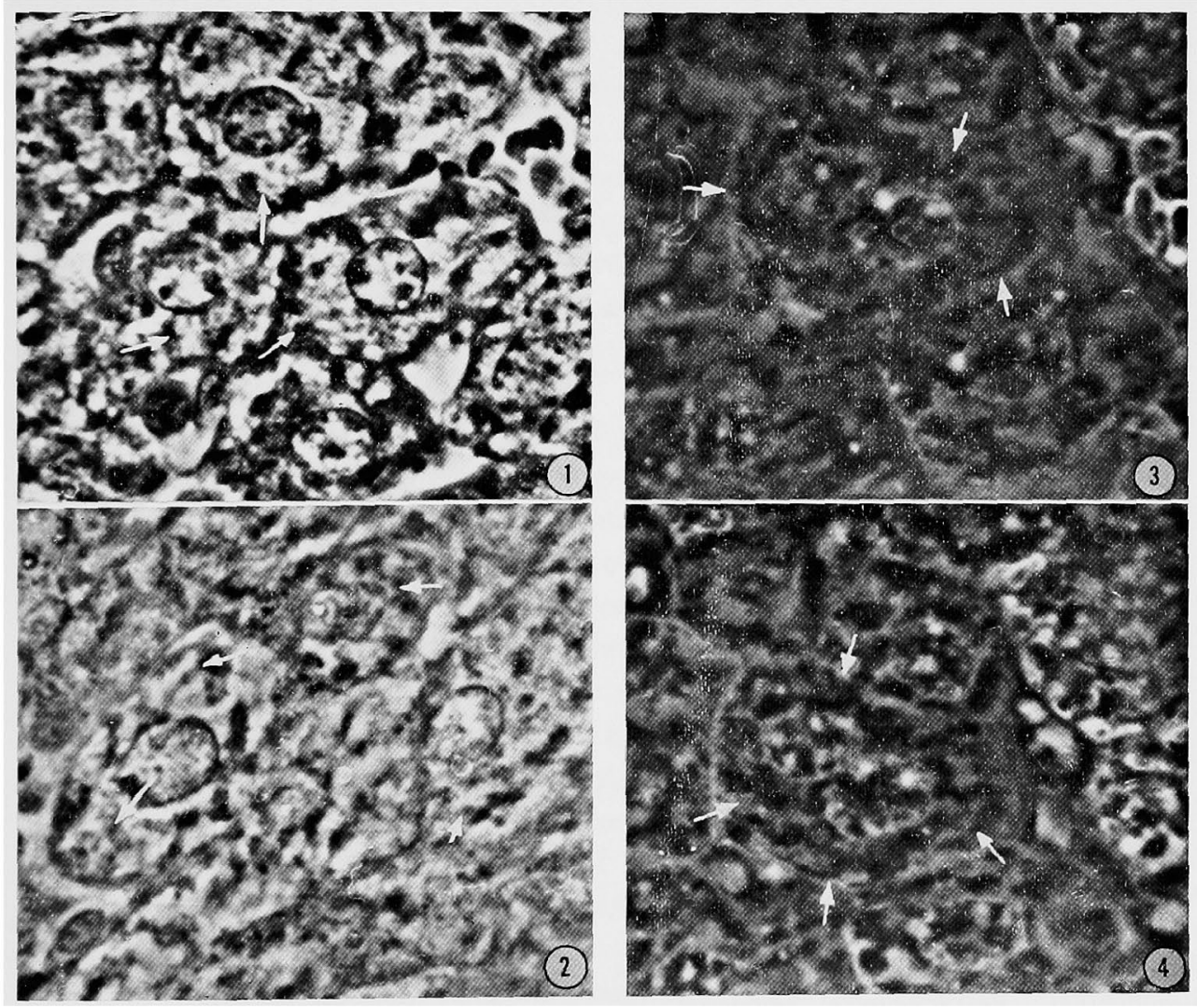

Figs. 1-4. 1-2, the Golgi element in hepatic cells of the white mouse (Mus musculus L. albino). Helly's fixation. Unstained. Phase contrast illumination. Refractometric technique. C. Zeiss (Jena) Lumipan phase contrast microscope. Oil immersion objective $\mathrm{Ph}$ HI 90/1.25, ocular K $10 \times \mathrm{T} . \quad 1, p$-xylene $(\mathrm{RI}=1.4968)$. 2, o-xylene $(\mathrm{RI}=1.5037)$. Photomicrographed with "Practina FX" camera. 3-4, the Golgi element in hepatic cells of the white mouse (Mus musculus L. albino). Schaffer's fixation. Unstained. Phase contrast illumination. Refractometric technique. 3, acetophenone $(\mathrm{RI}=1.5338)$. 4, di-methylaniline $(\mathrm{RI}=1.5589)$. Photomicrographed with "Practina FX" camera.

technique is most suitable for demonstrating the Golgi elements in the cells fixed but unstained. Phase negative or phase positive pictures obtained by this method, as I ascertained, correspond wholly to the pictures obtained after blackening the elements with silver salts by the methods of Cajal, Da Fano, 
Aoyama, Srivastava and Kruszyński. Mounting the sections in suitable media, especially those with an RI higher than 1.55 , I obtained phase positive pictures of the Golgi elements which resemble very much those obtained by impregnation with silver salts. Using, however, the media with RI lower than 1.52 gives pictures of phase negative Golgi elements which have the appearance of empty vacuoles and thin or thick canaliculi different in size and shape. Positive and negative phasing of the Golgi elements, observed

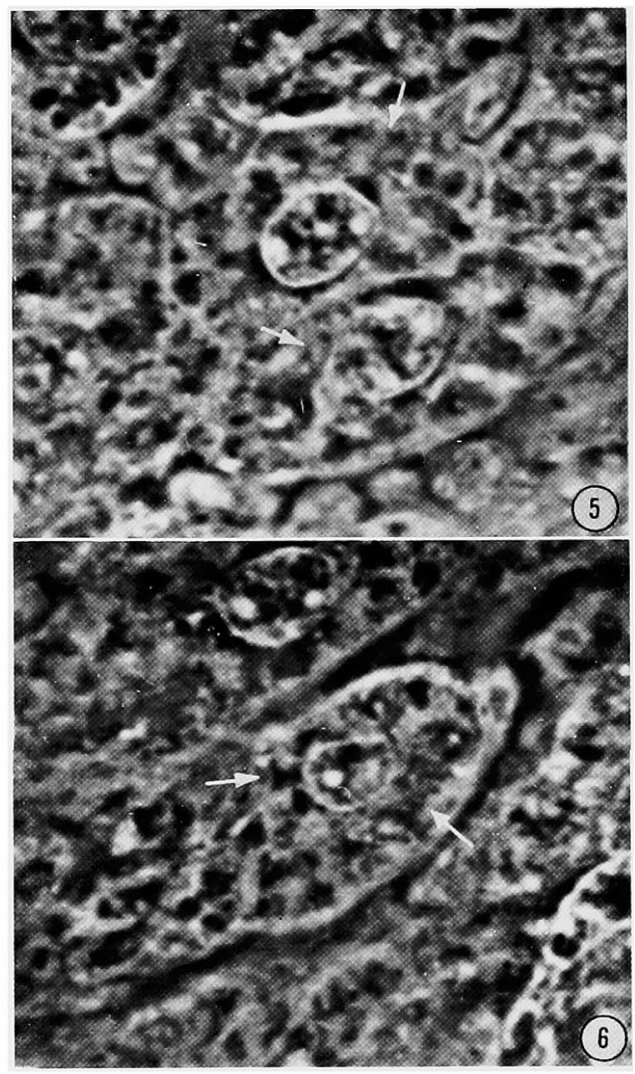

Figs. 5-6. The Golgi element in hepatic cells of the white mouse (Mus musculus L. albino). Helly's fixation. Unstained. Phase contrast illumination. Refractometric technique. 5, aniline ( $\mathrm{RI}=1.5828)$. 6, quinoline $(\mathrm{RI}=1.6161)$. Photomicrographed with "Practina FX" camera. in examined cells, makes the analysis of their location, shape and size possible. I noticed, however, in previous investigations that there may exist smaller or bigger differences in the morphology, size and location of the Golgi elements in the cells of the same organ which is fixed in different fixatives. After testing a lot of different fixatives I concluded that fixing the samples in Helly's fluid is the best for refractometric investigations. Analogous differences were noticed on fixing the samples of the mouse liver in Helly's and Schaffer's fluids.

Refractometric examinations in phase contrast illumination of the Golgi elements in the hepatic cells, previously fixed in Schaffer's and Helly's fluids, made it possible to detect that the elements were usually located near the nucleus and had appearance of vacuoles and rod-like or banana-like canaliculi. The canaliculi may be smooth or crenated, these latter being observed to consist of small or big granules arranged in a long or short row. The bigger the granules are, the shorter are the rods. If the granules are small, the rods are usually long and thin. Sometimes they even have the appearance of threads which form a net much resembling the typical Golgi apparatus (Figs. 1-6).

Phase negative vacuoles and canal-like structures, obtained on mounting the sections in $p$-xylene (1.4968) and $o$-xylene (1.5037), (Figs. 1-2), were observed to be located in mononucleated cells either at a small distance from 
the nucleus or attached to the nuclear membrane. The Golgi rods were usually crenated. They were arranged at a short distance from the nucleus like rays of an open umbrella or they formed more complicated structures which made up a typical Golgi net. Distribution and location of the elements of the Golgi net were different in various hepatic cells. Differences in the number, size and shape were visible (Figs. 1 and 2).

A similar differentiation of the Golgi elements was observed on mounting the sections in di-methylaniline (1.5589), aniline (1.5828) and quinoline (1.6161) which reversed the negative phase into a positive one (Figs. 4, 5 and 6). Complicated structures of the Golgi element were distinctly visible on immersion in quinoline because differences of phases between the examined object and the medium were great. Phase positive structures of the Golgi net were also refractometrically examined in binucleated hepatic cells. The Golgi material was profuse in them and occurred usually as crenated rods located very irregularly either around both the nuclei or throughout the whole of the protoplasm (Fig. 4). In spite of detailed examinations I did not succeed in detecting the canal-like structures to be attached to the typical Golgi net with one or two nuclei only. Granel (1929), however, using Cajal's method observed in binucleated cells the Golgi apparatus attached usually only to one nucleus.

In order to ascertain whether all the observed structures in binucleated cells are the Golgi elements, the sections were mounted in acetophenone (1.5338). Then the difference of contrast was very slight and the elements under examination were found more or less invisible and the contrast was zero (Fig. 3). Then it may be supposed that they have the same physical and chemical values and that they are the same cellular structure.

The application of refractometric technique and phase contrast illumination in the examinations of fixed and unstained hepatic cells made it possible to analyse in detail the morphology, shape, size and location of the Golgi elements. On the basis of my observations it seems to me that different distribution and different correlation of the Golgi elements depend on various phases of metabolic processes going on, not simultaneously, in all hepatic cells.

\section{Discussion}

The earlier workers have shown that silver nitrate fails to impregnate hepatic cells especially in demonstrating the Golgi material. Many workers were very sceptical about the results obtained by impregnation with silver nitrate. Kopsch (1926) reports, for example, that he did not succeed in demonstrating the Golgi apparatus in the hepatic cells. Ludford (1928), Dornesco (1930), Granel (1929) and others, using silver salts and osmic acid methods, observed in the hepatic cells of various animals the Golgi apparatus which did not always have the typical structure of the Golgi net. Cramer and Ludford (1926) and Ludford (1928) also, for example, described in the 
hepatic cells of the mouse, rat and guinea-pig single, loop-like bodies dispersed round the nucleus, while in the opinion of Dornesco (1929-1931) the Golgi apparatus consisted of vacuoles varying in number, which under the influence of fixatives formed themselves into elements resembling the net-like structure. Chodnik (1948) also reports that the Golgi material in the hepatic cells examined in birds fed and kept without food "consists of somewhat thick sausage-like rods with a few threads between them". He also reports that " $4 \mathrm{~h}$. after feeding, the Golgi material expands considerably and numerous granules arranged in rows, replace many of the links", while " $6 \mathrm{~h}$. after feeding, some granules are situated beyond the Golgi field in the form of large vesicles". According to Chodnik (1948) the Golgi material changes during the production of the secretory granules. Chodnik also follows Dornesco (1930) in the opinion concerning the existence of multipolarity of the Golgi zone in the hepatic cells.

The results of my investigations, carried out by refractometric technique and phase contrast illumination, show that the Golgi material in the hepatic cells of the mouse consists of the Golgi granules and crenated rods whose location may form complicated structures resembling in appearance the Golgi apparatus. In various hepatic cells the Golgi elements occurred always in varying number and their location in relation to the nucleus as well as their size and shape varied, all of them depending probably on different activity phases of the cells. Variability of the location, size and shape pointed also not only to the dynamics of changes going on in the Golgi elements but also to the possibility of changes in the Golgi zone of the cells or to its multipolarity. Hence the Golgi zone cannot be considered as something constant, unchangeable, characteristic of this type of cells. However Nassonov (1926), Bowen (1926), Ludford (1928) and others using silver nitrate methods considered the Golgi apparatus to be located always by that pole of the nucleus which is directed towards the bile capillary.

Multipolarity of the Golgi zone was distinctly marked in binucleated hepatic cells. The Golgi material in those cells was abundant and located uniformly, usually round both nuclei without special preference for either. One may say that the Golgi material occurs in the protoplasmatic zone which involves both nuclei. In this case I find it hard to accept the investigations of Granel, who described the Golgi apparatus located in binucleated cells attached to one nucleus only.

Multipolarity of the Golgi zone and especially the changeability of the picture of the Golgi elements, in the hepatic cells fixed in Schaffer's and Helly's fluids, but unstained, observed by me in refractometric investigations after using the media of known RI, seems to be closely related to the metabolism affecting changes in turgor and to the smaller or greater collection of inclusions in the cell. 


\section{Summary}

Refractometric investigations of the Golgi elements, by phase contrast illumination, were made in the hepatic cells of the white mouse, fixed in Schaffer's and Helly's fluids. Phase negative and phase positive pictures obtained by immersion in media of known $\mathrm{RI}$, beginning with $p$-xylene (RI= 1.4968) and ending with quinoline $(R I=1.6161)$ showed that the Golgi material in the examined cells consisted of the Golgi granules and crenated Golgi rods whose location may form complicated structures similar to the Golgi net. The Golgi elements which occurred in various hepatic cells always varied in number and they differed in size and shape and their location in relation to the nucleus was also different. The Golgi material in binucleated cells is very abundant and usually equally distributed round both nuclei without special preference for either.

The changeability in the location, size and shape point out not only to the dynamics of changes going on in the Golgi elements, but they indicate also the possibility of a change in the cells of the Golgi zone or the multipolarity of the zone.

The multipolarity of the Golgi zone in hepatic cells is probably closely related to the metabolism of the cells or to the smaller or greater collection of inclusions in them.

\section{Literature cited}

Bowen, R. H. 1926. Studies on the Golgi apparatus in gland cells. 1. Glands associated with the alimentary tract. Quart. J. micr. Sci. 70: 75-112.

Chodnik, K. S. 1948. Cytology of the glands associated with the alimentary tract of domestic fowl (Gallus domesticus). Quart. J. micr. Sci. 89: 75-87.

Cramer, W. and Ludford, R. J. 1926. On the cellular mechanism of bile secretion and its relation to the Golgi apparatus of the liver cell. J. Physiol. 62: 74-80.

Dornesco, G. Th. 1929. Constitution de la zone de Golgi de la cellule hépatique des poissons osseux. C. r. Soc. Biol. Paris 101: 127-129.

- 1929. Variations numériques des éléments de Golgi (vacuome) on cours du fonctionnement de la cellule hépatique des poissons osseux. C. r. Soc. Biol. Paris 101: 130132.

- 1929. L'appareil de Golgi dans les cellules hépatiques de Lacerta viridis. C. r. Soc. Biol. Paris 102: 366-369.

- 1930. La pluripolarité de la zone de Golgi des cellules hépatiques de la souris blanche. C. r. Soc. Biol. Paris 104: 390-392.

- 1931. L' appareil de Golgi des cellules hépatiques de Rana esculenta. C. r. Soc. Biol. Paris 107: $1224-1226$.

Gatenby, J. B. and Moussa, T. A. A. 1951. The nature of the Golgi apparatus. The liver cell and the Palade-Claude mash cytology. La Cellule 54: 51-64.

Gatenby, J. B. 1955. Light and electron microscopy of the Golgi apparatus, Dalton-Felix granules and cortical substance. La Cellule 57: 243-268.

Granel, F. 1929. Observations histologiques sur I' appareil de Golgi de la cellule hépatique du cobaye après injection d' hémoglobine. C. r. Assoc. Anat. 24: 257-266.

Graycki, S. 1958. Refractometry of the Golgi structure by phase contrast microscopy. Ann. Univ. M. Curie Skłodowska, Lublin. Sec. D. 13: 335-340. 
- 1959. Connective tissue fibres examined by phase contrast refractometry. Ann. Univ. M. Curie Sklodowska, Lublin. Sec. D. 14: 7-12.

- 1959. The morphology of the Golgi element examined refractometrically by phase contrast microscopy. Proc. zool. Soc. Calcutta 12: 59-70.

- 1960. Immersion refractometry of nucleolus by phase contrast illumination. Acta Anat. 41: 184-191.

- 1960. The effect of different fixatives on the Golgi structure examined by immersion refractometry in phase contrast illumination. Cytologia 25: 108-111.

- 1961. Examination of stained collagen fibres and fibroblasts by phase contrast microscopy. Z. mikr. anat. Forsch. 67: 389-397.

- 1961. Recherches refractometriques sur l'appareil de Golgi, au microscope à contraste de phase. Arch. Anat. Microsc. et Morphol. Exper. 50: 59-68.

- 1961. Examination of mitochondria by phase contrast refractometry. Acta Anat. 45: 124-132.

Hancox, N. M. and Krusyński, J. 1956. Refractometry of tissue sections by phase contrast microscopy. Exp. Cell Res. 11: 327-339.

Kopsch, F. 1926. Das Binnengerüst in den Zellen einiger Organe des Menschen. Z. mikr. anat. Forsch. 5: 221-284.

Kruszyński, J. 1957. Golgi structure of adenopituitary cells revealed by refractometry and microincineration. Exp. Cell Res. 13: 189-193.

- 1957. Species differences in the brush borders of kidney and intestine as revealed by refractometry with the phase microscope. Exp. Cell Res. 12: 108-114.

Ludford, R. J. 1928. The vital staining of normal and malignant cells. 1. Vital staining with Trypan Blue, and the cytoplasmic inclusions of liver and kidney cells. Proc. Roy. Soc. London. B. 103: 288-301.

Nassonov, D. 1926. Die physiologische Bedeutung des Golgi Apparates im Lichte der Vitalfärbungsmethode. Z. Zellforsch. 3: 472-502.

Pascual, J. A. 1924. Appareil de Golgi du foie, et pigment des fibres musculaires cardiaque et lisse. Trav. Labor. Rech. Biol. Univ. Madrid. 22: 191-208.

Subramaniam, M. K. 1938. Golgi material of the liver of Rhacophorus maculatus Gray. Proc. Indian Acad. Sci. B. 7: 80-125. 